\title{
Physical Methods for the Decontamination of Meat Surfaces
}

\author{
Thiemo Albert $^{1}$ (D) Peggy G. Braun ${ }^{1} \cdot$ Jasem Saffaf $^{1} \cdot$ Claudia Wiacek $^{1}$
}

Accepted: 20 January 2021 / Published online: 23 February 2021

(C) The Author(s) 2021

\begin{abstract}
Purpose of Review The market for minimally processed products is constantly growing due to consumer demand. Besides food safety and increased shelf life, nutritional value and sensory appearance also play a major role and have to be considered by the food processors. Therefore, the purpose of the review was to summarize recent knowledge about important alternative nonthermal physical technologies, including both those which are actually applied (e.g. high-pressure processing and irradiation) and those demonstrating a high potential for future application in raw meat decontamination (e.g. pulsed light UV-C and cold plasma treatment). The evaluation of the methods is carried out with respect to efficiency, preservation of food quality and consumer acceptance.

Recent Findings It was evident that significantly higher bacterial reductions are achieved with gamma-ray, electron beam irradiation and high pressure, followed by pulsed light, UV-C and cold plasma, with ultrasound alone proving the least effective. As a limitation, it must be noted that sensory deviations may occur and that legal approvals may have to be applied for.

Summary In summary, it can be concluded that physical methods have the potential to be used for decontamination of meat surfaces in addition to common hygiene measures. However, the aim of future research should be more focused on the combined use of different technologies to further increase the inactivation effects by keeping meat quality at the same time.
\end{abstract}

Keywords Cold plasma $\cdot$ Pulsed light $\cdot$ High-pressure $\cdot$ UV-C $\cdot$ Pathogens $\cdot$ Non-thermal

\section{Introduction}

Until recently, contamination of poultry, pork or beef carcasses by zoonotic pathogens and of the deboned and further processed fresh meat derived thereof has been one of the most challenging problems in food hygiene worldwide. From an epidemiological point of view, research and risk management approaches are aimed at reducing the prevalence as well as the bacterial load of Campylobacter, Salmonella, Yersinia

This article is part of the Topical Collection on Bacteriology

Claudia Wiacek

claudia.wiacek@vetmed.uni-leipzig.de

Thiemo Albert

albert@vetmed.uni-leipzig.de

Peggy G. Braun

pbraun@vetmed.uni-leipzig.de

Jasem Saffaf

saffaf@vetmed.uni-leipzig.de

1 Institute of Food Hygiene, Leipzig University, An den Tierkliniken 1, 04103 Leipzig, Germany enterocolitica, pathogenic Escherichia coli and Listeria monocytogenes, which have been the main cause of human foodborne infections in the EU, with over 350,000 reported cases in 2018 [1]. In recent decades, different strategies and measures have been applied, mainly at the pre-harvest level, but, except for in the case of Salmonella in poultry, with varying degrees of success. Therefore, recently developed strategies aim to include the entire processing chain, including transportation, stunning and slaughtering, deboning and further meat processing. In the case of Campylobacter in poultry, strategies should mainly be focused on post-harvest levels in order to significantly reduce the number of cases in humans [2]. In this context, the impact of physical, chemical and biological decontamination technologies has been the subject of a number of studies which have focussed on the potential use of chemical decontamination. Although a number of these appear to be promising alternatives, only a few can legally be applied during meat processing, e.g. the use of lactic acid for the decontamination of beef carcasses in the EU or the chlorination of poultry carcasses in various countries outside the EU. Physical methods, particularly dry interventions, are considered to be fast, mild and residue-free, and have received more attention. In contrast to chemical procedures, they can be 
applied more broadly across the processing chain and in some cases permit the treatment of pre-packaged meat, as well as frozen meat. Gamma irradiation has been most extensively studied and has in recent decades been supplemented with other technologies such as ultrasound, electron beam, UV light and high hydrostatic pressure treatment, as well emerging technologies e.g. light pulses or cold atmospheric plasma. Other treatments, such as electrical stimulation or pulsed electric fields (PEF), are largely intended for use in the acceleration of meat processing (tenderisation, drying, curing) rather than for decontamination purposes, and are therefore not considered in this review.

The article presents an overview of recently acquired knowledge concerning the impact of physical technologies on the decontamination of carcasses and fresh meat surfaces, including minced meat. It refers mainly to the treatment of poultry, pork and beef, and considers the most relevant bacterial zoonotic pathogens.

\section{Gamma Ray ( $\gamma$-Ray) and Electron Beam (e-Beam) Irradiation}

Food irradiation has already been applied for many decades and has been approved in around 60 countries around the world [3]. The exposure of food to ionizing radiation, either in form of electromagnetic energy ( $\gamma$-ray) or charged particles (e-beam) can improve the microbial safety of food and extend its shelf life, even resulting in the sterility of the product [4]. Whilst the radioisotopes caesium-137 or cobalt-60 are used as source of $\gamma$-rays, e-beams are produced by a linear accelerator. Irradiation inactivates microorganisms directly by photoninduced single and double-stranded DNA breaks, and indirectly by DNA damage, which is induced by radiolysis products, e.g. hydroxyl radicals [4]. The antimicrobial properties of both forms of irradiation are comparable, but e-beams allow a higher dose rate (e-beam $10^{3}-10^{5} \mathrm{~Gy} / \mathrm{s} ; \gamma$-ray $0.01-1 \mathrm{~Gy} / \mathrm{s}$ ), resulting in a shorter application time [5]. In contrast to ebeams, $\gamma$-rays penetrate deeper into the food matrix $(60$ $80 \mathrm{~cm}$ vs. $8-10 \mathrm{~cm}$ ) [6].

Complex life forms, which contain large DNA molecules, are affected by relatively low doses of less than $0.1 \mathrm{kGy}$, whilst simple life forms with smaller DNA such as bacteria $(1.5-4.5 \mathrm{kGy})$ or spores $(10-45 \mathrm{kGy})$ are inactivated at higher doses. In general, gram-negative bacteria are more sensitive to irradiation than gram-positive bacteria [4], but serotype and serovar variations have also been documented for E. coli [7] and Salmonella [8], respectively. Besides bacterial species, food composition (primarily water content), thickness and temperature also have an effect on irradiation efficiency. Frozen or dry foods need higher doses of $\gamma$-ray or e-beam [9], because low product temperatures reduce the diffusion of free radicals.
Irradiation has successfully been applied to meat products and raw meat for many years. Numerous studies (Table 1) of recent years deal with the reduction of pathogenic $E$. coli on meat using e-beams. For example, Amiri et al. 2019 [14], pointed out an E. coli $\mathrm{O} 157$ reduction $>6 \log$, below the detection limit in camel meat, and [9] determined a reduction of $>9 \log$ units in chicken breast and ground beef by a dose of $3.0 \mathrm{kGy}$. Salmonella was reduced $>1.9 \log$ or $6 \log$ in camel meat or beef using $1-5 \mathrm{kGy}[8,14]$, respectively. $\gamma$-Ray treatment also resulted in high reductions, as demonstrated in the case of E. coli in ground chicken $\mathrm{D}_{10} 0.18-0.68$ (about 2.5-7 $\log$ ) at $1.5 \mathrm{kGy}$ [13] and Campylobacter with a reduction of 5 $\log$ at $1 \mathrm{kGy}$ of irradiation [12].

It should be noted that both technologies lead to sensory changes as the dose of radiation increases. In particular, lipid and protein oxidation were observed in meat and poultry [16, 17]. Lipid oxidation may result in odour deviations and nutritional changes e.g. a decrease in unsaturated fatty acids [17]. For $\gamma$-ray irradiation, the alteration of vitamin content has also been reported [17].

Irradiated meat and meat products are already commercially available in some European countries, such as France, Belgium and the Netherlands. Processing plants also exist in Germany. The advantage of this technology is the possibility of treating frozen and packaged products. The International Atomic Energy Agency (IAEA), World Health Organization (WHO) and Food and Agriculture Organization (FAO) have confirmed that irradiation up to $10 \mathrm{kGy}$ assures the safety of food without undesirable effects on human health [18].

\section{Pulsed Light}

Pulsed light (PL) treatment, inter alia, pulsed UV-light (PUV), intense pulsed light (IPL) or HIPL (high-intensity pulsed light) is characterized as another rapid and gentle decontamination technology [19]. Inert gas flash lamps (mostly xenonbased) are used to generate very short ( $\mu$ s) high power pulses of broad-spectrum light. PL has a similar spectrum to sunlight with wavelengths from 200 to $1100 \mathrm{~nm}$ and encompasses ultraviolet (UV), visible (VIS) and infrared (IR) light, with an enormous output in the UV range [20]. Flashes of light have a higher decontamination efficiency than the continuous application of UV-light because the energy incorporated is multiplied manifold [21, 22].

The inactivation of microorganisms is a nonselective multitarget process, in which the photo-chemical effect is the most important mechanism. UV-C light is absorbed by DNA and pyrimidine dimers are formed, hindering DNA replication. The IR light component has a photo-thermal effect at higher powers [23], at which local overheating results in cell damage and cell ruptures [24]. The photo-physical effect is described by Takeshita et al. 2003 [25], who observed changes in cell 
Table 1 Overview on inactivation effects of $y$ - and e-beam irradiation on different bacteria

\begin{tabular}{|c|c|c|c|c|c|}
\hline Technology & Matrix & Bacterial species & Parameter & Maximum reduction & Reference \\
\hline \multirow[t]{12}{*}{$\gamma$-Irradiation } & Beef trimming & Escherichia coli STEC $(n=5)$ & $0.5-2.5 \mathrm{kGy}$ & $>5 \log \mathrm{CFU} / \mathrm{g}$ & {$[10]$} \\
\hline & Beef liver & Escherichia coli O157 $(n=2)$ & $0-3 \mathrm{kGy}$, air, $0{ }^{\circ} \mathrm{C} ;-80{ }^{\circ} \mathrm{C}$ & $\mathrm{D}_{10}: 0.26 ; 0.76$ & {$[11]$} \\
\hline & Beef liver & Escherichia coli 0157 & $0-3 \mathrm{kGy}$, vacuum; $0,-80^{\circ} \mathrm{C}$ & $\mathrm{D}_{10}: 0.41 ; 0.95$ & \\
\hline & Ground beef & Escherichia coli $0157(n=2)$ & $0-3 \mathrm{kGy}$ air, $0{ }^{\circ} \mathrm{C} ;-80^{\circ} \mathrm{C}$ & $\mathrm{D}_{10}: 0.25 ; 0.51$ & \\
\hline & Ground beef & Escherichia coli 0157 & $0-3 \mathrm{kGy}$, vacuum; $0,-80^{\circ} \mathrm{C}$ & $\mathrm{D}_{10}: 0.35 ; 0.78$ & \\
\hline & Beef liver & Salmonella Enteritidis & $0-5 \mathrm{kGy}$ air, $0{ }^{\circ} \mathrm{C},-80^{\circ} \mathrm{C}$ & $\mathrm{D}_{10}: 0.65 ; 1.38$ & \\
\hline & Beef liver & Salmonella Enteritidis & $0-5 \mathrm{kGy}$, vacuum; $0{ }^{\circ} \mathrm{C},-80{ }^{\circ} \mathrm{C}$ & $\mathrm{D}_{10}: 0.67 ; 1.47$ & \\
\hline & Ground beef & Salmonella Enteritidis & $0-5$ kGy air, $0{ }^{\circ} \mathrm{C},-80{ }^{\circ} \mathrm{C}$ & $\mathrm{D}_{10}: 0.58 ; 1.00$ & \\
\hline & Ground beef & Salmonella Enteritidis & $0-5 \mathrm{kGy}$, vacuum; $0{ }^{\circ} \mathrm{C},-80{ }^{\circ} \mathrm{C}$ & $\mathrm{D}_{10}: 0.60 ; 1.03$ & \\
\hline & Chicken meat & Campylobacter jejuni & $1 \mathrm{kGy}$ & $5 \mathrm{log}$ CFU/g & {$[12]$} \\
\hline & Ground chicken & Escherichia coli UPEC cocktail & $0-2.1 \mathrm{kGy}, 4^{\circ} \mathrm{C},-20^{\circ} \mathrm{C}$ & $\mathrm{D}_{10}: 0.28-0.36$ & [7] \\
\hline & Ground chicken & Escherichia coli $(n=22:$ UPEC, NMEC, CS, CM) & $0-1.5 \mathrm{kGy}$ & $\mathrm{D}_{10}: 0.18-0.68$ & [13] \\
\hline \multirow[t]{7}{*}{ e-Beam } & Minced camel meat & Escherichia coli $0157: H 7$ & $1-5 \mathrm{kGy}$ & $6.17 \log \mathrm{CFU} / \mathrm{g}$ & {$[14]$} \\
\hline & Minced camel meat & Salmonella Typhimurium & $1-5 \mathrm{kGy}$ & $6.17 \log \mathrm{CFU} / \mathrm{g}$ & \\
\hline & Beef meat & Escherichia coli non O157, O157:H7 $(n=32)$ & $1 \mathrm{kGy}$ & $\max . \leq 4.5 \log \mathrm{CFU} / \mathrm{g}$ & {$[8]$} \\
\hline & Ground beef & Escherichia coli O1587:H7 & $0.5-3 \mathrm{kGy},-20 \mathrm{C}, 4^{\circ} \mathrm{C} ; 22^{\circ} \mathrm{C}$ & $\mathrm{D}_{10}: 0.33 / 0.24 / 0.22$ & [9] \\
\hline & Beef meat & Salmonella $(n=6)$ & $1 \mathrm{kGy}$ & $\leq 1.9 \log \mathrm{CFU} / \mathrm{g}$ & {$[8]$} \\
\hline & Chicken breast & Escherichia coli $\mathrm{O} 1587: \mathrm{H} 7$ & $0.5-3 \mathrm{kGy},-20{ }^{\circ} \mathrm{C}, 4{ }^{\circ} \mathrm{C} ; 22{ }^{\circ} \mathrm{C}$ & $\bar{D}_{10}: 0.35 / 0.30 / 0.26$ & {$[9]$} \\
\hline & Chicken breast filet & Escherichia coli & $1 ; 1.8 \mathrm{kGy}$ & $>2.1 \mathrm{CFU} / 200 \mathrm{ml}$ & [15] \\
\hline
\end{tabular}

CFU: colony-forming units

$\mathrm{D}_{10}$ : radiation dose $[\mathrm{kGy}]$ to reduce the exposed microbial population by $90 \%$ (one $\log 10$ )

shape and cell membrane, cytoplasmic damage and the leakage of intracellular compounds. The majority of publications reported a higher resistance of gram-positive bacteria in comparison to gram-negative bacteria [19] but strain-dependent susceptibility has also been observed [26]. The inactivation of fungal and bacterial spores differs and depends on the presence of pigments [27].

Actual reductions achieved on meat surfaces range from $0.9 \mathrm{log}$ for Listeria monocytogenes on vacuum-packed beef carpaccio [28] to $4.39 \log$ for Yersinia enterocolitica on pork skin [29] (Table 2). Decontamination of skinless chicken thigh or breast has been reported of various pathogens at 2.09-3.0 $\log$. The range of reduction on chicken thigh with skin was 1.82-1.96 log, depending on the conditions used (Table 2). Efficiency strongly depends on energy input (fluence $\mathrm{J} / \mathrm{cm}^{2}$ ), product surface and composition. Opaque and non-uniform surfaces limit the effect due to shading effects caused by pores and cracks [21]. High fat and protein content reduce treatment effectiveness due to increased UV absorption [19].

Effects on sensory behaviour are well documented [29, 31, $34,47,48]$. Depending on the energy input and the kind of meat, colour and odour changes have been detected. Beef, pork and deer meat decreased in redness, whilst chicken colour increased in lightness at high fluences [33, 48]. From the perspective of consumers, odour changes or off-flavours are a bigger issue. Significant changes have been described in the case of pork and chicken meat by Koch et al. 2019 [29] and McLeod et al. 2018 [31], even at low fluences. The offflavours may have been induced by the formation of ozone and nitrogen oxides which arise during treatment in the PL chamber [29]. Accelerated lipid peroxidation was indeed measured but only in low concentrations and this was not detected by panellists [29, 31, 34, 47].

PL technology is a surface decontamination method, as the light penetrates only a few $\mu \mathrm{m}$ into the surface [23]. The main advantages are very short treatment times, the ability to inactivate bacterial spores, a lack of chemical residues and operation in batch or continuous mode. Although PL was approved by the FDA in 1996 for food disinfection, at present, it is only used in the food packaging industry, and not at a large scale.

\section{Ultraviolet (UV-C) Light}

UV-C (200-280 nm), a type of the ultraviolet light (100$400 \mathrm{~nm}$ ), can help sterilize liquids, indoor air or surfaces [49-51]. Unfortunately, it is still underused in the food industry. The major goal of all studies has been to reduce pathogenic microorganisms in food products and extend shelf life without impairing freshness [35, 42, 44]. UV-C light generates photoproducts during treatment (pyrimidine pyrimidone (64) and pyrimidine dimers) resulting in damage to microbial DNA and proteins in living cells. DNA damage may involve the crosslinking of the strong hydrogen bonds between the nucleobases thymine-cytosine. DNA-transcription and replication are thus disturbed, which can disable repair processes, and cause mutations and cell death [52]. In relation to raw meat decontamination, several research groups have examined the potential of UV-C LEDs for the reduction of microbial load. For example, with doses of up to $2040 \mathrm{~mJ} / \mathrm{cm}^{2}, 0.56,0.82$ and 
Table 2 Overview on inactivation effects of pulsed light and UV-irradiation on different bacteria

\begin{tabular}{|c|c|c|c|c|c|}
\hline Technology & Matrix & Bacterial species & Parameter & Maximum reduction & Reference \\
\hline \multirow[t]{21}{*}{ Pulsed light } & Lean chicken tights & Campylobacter jejuni & $3.38-62.24 \mathrm{~J} / \mathrm{cm}^{2}$ & $2.09 \log \mathrm{CFU} / \mathrm{cm}^{2}$ & \multirow[t]{4}{*}[30]{} \\
\hline & Chicken tights' skin & Campylobacter jejuni & $3.38-62.24 \mathrm{~J} / \mathrm{cm}^{2}$ & $1.85 \mathrm{log} \mathrm{CFU} / \mathrm{cm}^{2}$ & \\
\hline & Lean chicken tights & Escherichia coli & $3.38-62.24 \mathrm{~J} / \mathrm{cm}^{2}$ & $2.02 \mathrm{log} \mathrm{CFU} / \mathrm{cm}^{2}$ & \\
\hline & Chicken tights' skin & Escherichia coli & $53.38-62.24 \mathrm{~J} / \mathrm{cm}^{2}$ & $1.96 \log \mathrm{CFU} / \mathrm{cm}^{2}$ & \\
\hline & Skinless chicken filet & Escherichia coli (EHEC) & $1.25-18 \mathrm{~J} / \mathrm{cm}^{2}$ & $3.0 \log \mathrm{CFU} / \mathrm{cm}^{2}$ & \multirow[t]{2}{*}[31]{} \\
\hline & Skinless chicken filet & Escherichia coli (ESBL) & $1.25-18 \mathrm{~J} / \mathrm{cm}$ & $2.8 \log \mathrm{CFU} / \mathrm{cm}^{2}$ & \\
\hline & Lean chicken tights & Salmonella Typhimurium & $3.38-62.24 \mathrm{~J} / \mathrm{cm}^{2}$ & $2.42 \mathrm{log} \mathrm{CFU} / \mathrm{cm}^{2}$ & \multirow[t]{2}{*}[30]{} \\
\hline & Chicken tights' skin & Salmonella Typhimurium & $53.38-62.24 \mathrm{~J} / \mathrm{cm}^{2}$ & $1.82 \mathrm{log} \mathrm{CFU} / \mathrm{cm}^{2}$ & \\
\hline & Skinless chicken breast & Salmonella Typhimurium & $0.78-5.4 \mathrm{~J} / \mathrm{cm}^{2}$ & $2.0 \log \mathrm{CFU} / \mathrm{g}$ & {$[32]$} \\
\hline & Chicken breast & Salmonella Typhimurium & $2.7-67 \mathrm{~J} / \mathrm{cm}^{2}$ & $2.4 \log \mathrm{CFU} / \mathrm{cm}^{2}$ & [33] \\
\hline & Skinless chicken filet & Salmonella Enteritidis & $1.25-18 \mathrm{~J} / \mathrm{cm}$ & $2.4 \log \mathrm{CFU} / \mathrm{cm}^{2}$ & \multirow[t]{2}{*}[31]{} \\
\hline & Chicken filet & Listeria monocytogenes & $1.25-18 \mathrm{~J} / \mathrm{cm}$ & $2.0 \log \mathrm{CFU} / \mathrm{cm}^{2}$ & \\
\hline & Skinless chicken breast & Listeria monocytogenes & $0.78-5.4 \mathrm{~J} / \mathrm{cm}^{2}$ & $2.4 \log \mathrm{CFU} / \mathrm{g}$ & {$[34]$} \\
\hline & Skinless chicken filet & Staphylococcus aureus & $1.25-18 \mathrm{~J} / \mathrm{cm}^{2}$ & $3.0 \log \mathrm{CFU} / \mathrm{cm}^{2}$ & {$[31]$} \\
\hline & Beef carpaccio & Listeria monocytogenes & $0.7-11.9 \mathrm{~J} / \mathrm{cm}^{2}$ & $0.9 \log \mathrm{CFU} / \mathrm{cm}^{2}$ & \multirow[t]{3}{*}{ [28] } \\
\hline & Beef carpaccio & Escherichia coli & $0.7-11.9 \mathrm{~J} / \mathrm{cm}^{2}$ & $1.2 \log \mathrm{CFU} / \mathrm{cm}^{2}$ & \\
\hline & Beef carpaccio & Salmonella Typhimurium & $0.7-11.9 \mathrm{~J} / \mathrm{cm}^{2}$ & $1.0 \log \mathrm{CFU} / \mathrm{cm}^{2}$ & \\
\hline & Pork skin & Salmonella ser. Typhimurium & $0.52-19.11 \mathrm{~J} / \mathrm{cm}^{2}$ & $3.16 \log \mathrm{CFU} / \mathrm{cm}^{2}$ & \multirow{4}{*}{ [29] } \\
\hline & Pork loin & Salmonella ser. Typhimurium & $0.52-19.11 \mathrm{~J} / \mathrm{cm}^{2}$ & $1.7 \log \mathrm{CFU} / \mathrm{cm}^{2}$ & \\
\hline & Pork skin & Yersinia enterocolitica & $0.52-19.11 \mathrm{~J} / \mathrm{cm}^{2}$ & $4.37 \log \mathrm{CFU} / \mathrm{cm}^{2}$ & \\
\hline & Pork loin & Yersinia enterocolitica & $0.52-19.11 \mathrm{~J} / \mathrm{cm}^{2}$ & $1.7 \log \mathrm{CFU} / \mathrm{cm}^{2}$ & \\
\hline \multirow[t]{35}{*}{ UV-C } & Chicken breast & Escherichia coli & $7.8 \mathrm{~J} / \mathrm{cm}^{2}$ & $1.6 \log \mathrm{CFU} / \mathrm{ml}$ & {$[35]$} \\
\hline & \multirow[t]{4}{*}{ Chicken fillet } & Salmonella Enteritidis $(n=3)$ & $0.05-3.00 \mathrm{~J} / \mathrm{cm}^{2}$ & $2.4 \log \mathrm{CFU} / \mathrm{cm}^{2}$ & \multirow[t]{4}{*}[31]{} \\
\hline & & Listeria monocytogenes $(n=4)$ & & $1.8 \log \mathrm{CFU} / \mathrm{cm}^{2}$ & \\
\hline & & Staphylococcus aureus $(n=3)$ & & $2.6 \log \mathrm{CFU} / \mathrm{cm}^{2}$ & \\
\hline & & Enterohaemorrhagic Escherichia coli $(n=4)$ & & $1.7 \log \mathrm{CFU} / \mathrm{cm}^{2}$ & \\
\hline & Chicken breast & Uropathogenic Escherichia coli $(n=6)$ & $120 \mathrm{~mJ} / \mathrm{cm}^{2}$ & $0.6 \log \mathrm{CFU} / \mathrm{g}$ & [7] \\
\hline & \multirow{3}{*}{ Chicken skin } & Campylobacter jejuni $(n=10)$ & $0.192 \mathrm{~J} / \mathrm{cm}^{2}$ & $0.52 \log \mathrm{CFU} / \mathrm{g}$ & \multirow{6}{*}{ [36] } \\
\hline & & Escherichia coli & & $0.67 \log \mathrm{CFU} / \mathrm{g}$ & \\
\hline & & Salmonella Enteritidis & & $0.70 \log \mathrm{CFU} / \mathrm{g}$ & \\
\hline & \multirow[t]{3}{*}{ Chicken breast } & Campylobacter jejuni $(n=10)$ & $0.192 \mathrm{~J} / \mathrm{cm}^{2}$ & $0.76 \log \mathrm{CFU} / \mathrm{g}$ & \\
\hline & & Escherichia coli & & $0.88 \log \mathrm{CFU} / \mathrm{g}$ & \\
\hline & & Salmonella Enteritidis & & $1.34 \log \mathrm{CFU} / \mathrm{g}$ & \\
\hline & \multirow[t]{3}{*}{ Chicken drumstick } & Salmonella $(n=3)$ & $4 \mathrm{~J} / \mathrm{cm}^{2}$ & $0.45 \log \mathrm{CFU} / \mathrm{g}$ & \multirow{6}{*}[37]{} \\
\hline & & Staphylococcus aureus $(n=3)$ & & $0.42 \log \mathrm{CFU} / \mathrm{g}$ & \\
\hline & & Listeria monocytogenes $(n=3)$ & & $0.63 \log \mathrm{CFU} / \mathrm{g}$ & \\
\hline & Chicken breast & Salmonella $(n=3)$ & $4 \mathrm{~J} / \mathrm{cm}^{2}$ & $0.32 \log \mathrm{CFU} / \mathrm{g}$ & \\
\hline & & Staphylococcus aureus $(n=3)$ & & $0.44 \log$ CFU/g & \\
\hline & & Listeria monocytogenes $(n=3)$ & & $0.37 \log \mathrm{CFU} / \mathrm{g}$ & \\
\hline & Broiler meat & Campylobacter jejuni & $33 \mathrm{~mW} / \mathrm{cm}^{2}$ & $0.70 \log \mathrm{CFU} / \mathrm{g}$ & [38] \\
\hline & Broiler skin & Campylobacter jejuni & $33 \mathrm{~mW} / \mathrm{cm}^{2}$ & $0.80 \log \mathrm{CFU} / \mathrm{g}$ & \\
\hline & Chicken breast & Yersinia pestis $(n=4)$ & $1 \mathrm{~J} / \mathrm{cm}^{2}$ & About $1 \log$ CFU/g & [39] \\
\hline & Beef steak & Yersinia pestis $(n=4)$ & $1 \mathrm{~J} / \mathrm{cm}^{2}$ & & \\
\hline & Beef & Escherichia coli $(n=2)$ & $590 \mathrm{~mJ} / \mathrm{cm}^{2}$ & $1.19 \log \mathrm{CFU} / \mathrm{cm}^{2}$ & {$[40]$} \\
\hline & & Salmonella strains $(n=2)$ & & $1.08 \mathrm{log} \mathrm{CFU} / \mathrm{cm}^{2}$ & \\
\hline & & Listeria monocytogenes $(n=2)$ & & $0.89 \log \mathrm{CFU} / \mathrm{cm}^{2}$ & \\
\hline & Beef & Escherichia coli & $7.8 \mathrm{~J} / \mathrm{cm}^{2}$ & $1.0 \log \mathrm{CFU} / \mathrm{ml}$ & {$[35]$} \\
\hline & Beef & Escherichia coli $\mathrm{O} 157: \mathrm{H} 7$ & $4.5 \mathrm{~mW} / \mathrm{cm}^{2}$ & About $1 \log \mathrm{CFU} / \mathrm{g}$ & {$[41]$} \\
\hline & & Salmonella Typhimurium & & & \\
\hline & & Listeria monocytogenes & & & \\
\hline & Pork & Escherichia coli & $7.8 \mathrm{~J} / \mathrm{cm}^{2}$ & $1.6 \log \mathrm{CFU} / \mathrm{ml}$ & {$[35]$} \\
\hline & Pork & Yersinia enterocolitica & $2040 \mathrm{~mJ} / \mathrm{cm} 2$ & $0.56 \log \mathrm{CFU} / \mathrm{g}$ & [42] \\
\hline & Pork & Arcobacter butzleri $(n=3)$ & $108-648 \mathrm{mWs} / \mathrm{cm}^{2}$ & $1.29 \mathrm{CFU} / \mathrm{mL}$ & [43] \\
\hline & Pork & Salmonella (3 strains) & $4 \mathrm{~J} / \mathrm{cm}^{2}$ & $0.53 \log \mathrm{CFU} / \mathrm{g}$ & {$[37]$} \\
\hline & & Staphylococcus aureus $(n=3)$ & & $0.49 \log \mathrm{CFU} / \mathrm{g}$ & \\
\hline & & Listeria monocytogenes $(n=3)$ & & $0.65 \log \mathrm{CFU} / \mathrm{g}$ & \\
\hline UV-C and phages & Chicken breast & Listeria monocytogenes $(n=3)$ & 6 phages and & $2.04 \log \mathrm{CFU} / \mathrm{g}$ & {$[44]$} \\
\hline & & & $600-2400$ & & \\
\hline UV-C and chlorine & Chicken breast & Listeria monocytogenes $(n=3)$ & $\begin{array}{c}\mathrm{mWs} / \mathrm{cm}^{-} \\
300 \mathrm{~mW} \cdot \mathrm{cm}^{2}\end{array}$ & $0.8 \log \mathrm{CFU} / \mathrm{g}$ & [45] \\
\hline & & & and chlorine $(200 \mathrm{mg} / \mathrm{kg})$ & & \\
\hline $\begin{array}{l}\text { UV-C and crust } \\
\text { freezing }\end{array}$ & Chicken drumsticks & Campylobacter jejuni & $\begin{array}{c}\left(-27,-15,-5^{\circ} \mathrm{C}\right) \\
\quad \text { and } 0.048 \mathrm{~J} / \mathrm{cm}^{2}\end{array}$ & About $1.0 \log \mathrm{CFU} / \mathrm{g}$ & {$[46]$} \\
\hline
\end{tabular}

CFU: colony-forming units; EHEC: Enterohaemorrhagic Escherichia coli; ESBL: Extended Spectrum Beta-Lactamase 
$0.95 \log$ reductions were achieved for Yersinia enterocolitica on pork after 1, 7 and 14 days of storage (Table 2), respectively [42]. Similar results were reported at $1 \mathrm{~J} / \mathrm{cm}^{2}\left(1000 \mathrm{~mJ} / \mathrm{cm}^{2}\right) \mathrm{UV}-\mathrm{C}$ for Yersinia pestis on chicken breast filets and beef steaks [39]. In another study, greater reductions of up to 2.4, 1.8, 2.6 and 1.7 log were obtained for Salmonella Enteritidis, Listeria monocytogenes, Staphylococcus aureus and enterohaemorrhagic Escherichia coli, respectively, when chicken filets were irradiated with doses of up to $3 \mathrm{~J} / \mathrm{cm}^{2}$ at a distance of $6 \mathrm{~cm}$ [31]. In addition, combined treatments were investigated to improve microbial reductions on raw meat $[45,53]$. UV-C treatment at $590 \mathrm{~mJ} / \mathrm{cm}^{2}$ reduced Listeria monocytogenes, Salmonella strains and Escherichia coli O157: H7 on fresh beef by 0.89, 1.08 and $1.19 \log$. Combination treatment with gaseous ozone significantly decreased the pathogens to $1.14,1.33$ and $1.42 \mathrm{log}$, respectively [40], whilst synergistic treatment of Listeria monocytogenes with UV-C light and phage on chicken breast resulted in a reduction of up to $2.04 \log$ [44]. By contrast, only $0.8 \mathrm{log}$ reduction of Listeria monocytogenes on chicken meat was observed after combined treatment with chlorine (200 mg/kg) and UV-C (300 mW/ $\left.\mathrm{cm}^{2}\right)$ [45]. Furthermore, most studies examined the impact of UV-C irradiation on organoleptic properties, such as the colour and texture of raw meat. The authors reported that there was minimal to zero influence on the quality parameters of the samples treated [40, 42, 45]. UV$\mathrm{C}$ radiation can help reduce the microbes on the surface of the meat but not able to completely eliminate them. For this reason, it is recommended to use this method in combination with other decontamination technologies to improve the microbial safety of raw meat.

\section{Cold Atmospheric Plasma}

Non-thermal atmospheric plasma or cold plasma is another of many emerging food preservation technologies which can effectively reduce food-borne pathogens with only minimal detectable effects on product quality, or with none at all $[54,55]$. In recent years, many plasma-generating devices have been used in order to investigate their antibacterial potency on various food products [56-59]. In general, cold plasma consists of UV photons, excited atoms and molecules, electrons, ions, free radicals and reactive species (atomic oxygen, hydroxyl radicals, ozone, nitrogen oxides, singlet oxygen and superoxide), which have the ability to kill bacteria, viruses and fungi $[60,61]$. These compounds cause cell misfunction through the lesions in the membrane, the breaking of chemical bonds in the cell wall, intracellular disorder, loss of enzyme activity, denaturation of proteins and damage to RNA and DNA, which can lead to bacterial cell death [62-67]. Since 2015, several studies have significantly increased knowledge of cold plasma and its applications in the food industry. Treatment with dielectric-barrier discharge (DBD) cold plasma has been examined particularly intensively [54, 68, 69]. The DBD plasma system consists of a high voltage source, a high voltage electrode, a ground electrode and a dielectric barrier. The electrical discharge occurs between the electrodes through the application of an alternating current and high voltage [70]. This method can therefore reduce the number of microorganisms ( $\geq 2$ log-units) on foods and food products within the package, avoiding re-contamination $[68,71]$. Treatment of red meat with DBD (voltage $15 \mathrm{kHz}$ ) resulted in the reduction of Listeria monocytogenes, Escherichia coli O157: H7 and Salmonella Typhimurium by up to $2.04,2.54$ and $2.68 \mathrm{log}$ units on pork butt, of 1.90, 2.57 and $2.58 \mathrm{log}$-units on beef loin and of $2.14,2.73$ and 2.71 log-units on chicken breast (Table 3), respectively [54, 72]. The shelf life of chicken breast filets has also been increased by up to 2 weeks by using cold plasma in modified atmosphere packaging $\left(65 \% \mathrm{O}_{2}, 30 \%\right.$ $\mathrm{CO}_{2}$ and $5 \% \mathrm{~N}_{2}$ ) stored at $4{ }^{\circ} \mathrm{C}[75,76]$. After $120 \mathrm{~h}$, posttreatment with DBD (at $70 \mathrm{kV}$ for $300 \mathrm{~s}$ ) resulted in a reduction of approximately $1 \log$ for Campylobacter jejuni and Salmonella Typhimurium on chicken breast filets stored at $4{ }^{\circ} \mathrm{C}(P<0.05)$ [69]. With the two-dimensional array of an integrated coaxial microhollow DBD device, it was possible to reduce the presence of Salmonella enterica Serovar Heidelberg by up to $3.7 \log$ on chicken breast [68]. Combining this treatment with peracetic acid has proven successful for minimizing the presence of Salmonella Typhimurium on skinless chicken meat. Different hurdle interventions of peracetic acid (100-200 ppm) and atmospheric cold plasma (voltage $0-30 \mathrm{kV}$ ) were used to improve the antibacterial effect against pathogenic agents. Although this combined treatment did achieve significant inactivation of up to $5.3 \mathrm{log}$, it caused qualitative changes in the colours and moisture content of chicken meat [74•]. Direct treatment with plasma jet on raw chicken samples has been reported by Rossow et al. [57]. Argon and air were used as the feed gas to generate plasma by means of a jet. After $180 \mathrm{~s}$, Campylobacter jejuni was reduced by around $2.50 \mathrm{log}$ on skin and muscle.

Most studies, however, reported that changes in quality during plasma treatment were very limited $[54,55,72,73$, 77]. This technology is environmentally friendly, with no chemical or organic residues, and has great potential. It could, for example, also be used to decontaminate equipment which has come into contact with meat or other foodstuffs, such as cutting tools [78]. It should be regarded as a future technology in the food industry for the enhancement of food safety.

Other authors used non-thermal plasma-activated water (PAW) to reduce microbial load on food [58, 74•]. PAW can be generated using two different methods. Activation occurs either in or above the water. In the case of the first method, cold plasma is discharged within bubbles, with the plasma source operating underwater [79]. In the case of the second method, the discharges occur in the space $(3 \mathrm{~mm})$ between 
four single plasma jets and the surface of the solution [80]. Generally, PAW has a low $\mathrm{pH}$ and contains reactive oxygen and nitrogen species (RONS,) which play a major role in disrupting microbes $[81,82]$. PAW has been used to reduce Salmonella Enteritidis on slices of beef by about 1 log level. To improve efficiency, the slices of beef were treated with different types of plasma-activated lactic acid. However, whilst this combined treatment resulted in a reduction in Salmonella load of up to $3.52 \log$ [55], Escherichia coli and Staphylococcus aureus achieved only up to only 1.12, 0.86 $\log$ on skin and $1.33,0.83 \log$ on muscle respectively after treatment with PAW and ultrasound [58].

\section{High Pressure}

High pressure processing (HPP) is a non-thermal, residuefree technology and has been applied in the food industry for several decades. For application, the food is vacuumpackaged in a flexible and water-proof package and submitted to a pressure vessel to pressures generally ranging from 100 to $600 \mathrm{MPa}$, depending on the product. This takes a few minutes and is carried out at ambient temperatures [83]. In contrast to most other technologies, HPP treats the whole product, as the isostatic pressure affects the food product virtually instantaneously and uniformly, regardless of geometry and size [84].

Small molecules, such as vitamins and flavour compounds are unaffected, which is relevant to the taste and nutritional value of the product. HPP affects noncovalent bonds (electrostatic and hydrophobic interactions) therefore macromolecules such as proteins are subjected to changes in their tertiary and quaternary structures [85]. Consequently, cell structures are disrupted by protein denaturation, lipid conformation and enzyme inactivation, which promote the inactivation of microorganisms. Bacteria are generally more resistant than yeast and moulds and, with some exceptions, gram-positive bacteria are more resistant than gram-negative bacteria [86]. In addition, variations between strains in resistance to pressure have been demonstrated e.g. by Tamber [87.•] in the case of Salmonella. Diverse studies have shown the efficiency of HPP in the reduction of pathogenic bacteria in raw poultry, beef and pork meat and organs (Table 4). Over the past 5 years, most studies were focused on the applicability to chicken meat and beef, with the focus being on various pathogenic E. coli strains, whereby high reductions of between 4 and $>7 \log$ were demonstrated, some within periods of 4 min [97]. Additionally, Salmonella spp. and Listeria spp. were significantly reduced by $3.4-7.78 \mathrm{log}$ after HPP treatment in chicken filet, depending on pressure and holding time. Generally, a higher pressure and longer pressure holding time increased the efficiency of the treatment, as shown for Salmonella and E. coli on chicken breast, where an increase from 200 to $300 \mathrm{MPa}$ enhanced reduction to about $1-1.3 \log$ and $0.3-1.4 \log$ respectively when increasing the holding time by $5 \mathrm{~min}$ [93]. Using higher pressure can reduce the holding time, an important aspect for industrial applications. Unfortunately, increased pressure may accelerate the sensory deviations of the meat in terms of appearance, colour or texture. At $>300 \mathrm{MPa}$, colour modifications were particularly observable in red and white meats. This is caused by myoglobin alterations and colours becoming browner in beef and lighter in pork and poultry [106]. Induced lipid oxidation was detected in fresh beef, poultry meat and pork at $>300 \mathrm{MPa}$, most often occurring during subsequent storage [107].

HPP treatment enhances safety, extends the shelf life of meat and has good consumer acceptance [108]. The application is free from additives and can be used for packaged meat. Its efficiency can be further improved through combination with heat at approximately $60^{\circ} \mathrm{C}$, the use of specific additives, or active packaging [107]. There are more than 300 HPP industrial facilities worldwide, with a share of $26 \%$ pressuretreated meat products [109]. Various HPP meat products, such as sliced and cooked ham, meat cuts or RTE products, are also commercially distributed in Europe.

\section{Ultrasound}

Ultrasound treatment or ultrasonication (US) is an emerging technology for diverse applications in food and nonfood areas which has been known of for some time. Ultrasound is defined as sound waves with frequencies higher than the upper limit of human hearing $(20 \mathrm{kHz})$ and is therefore distinct from audible and infrasonic waves. In detail, US can be divided into power ultrasound (16$100 \mathrm{kHz})$, high-frequency ultrasound $(100 \mathrm{kHz}-1 \mathrm{MHz})$ and diagnostic ultrasound (1-10 MHz). US is already used in a variety of applications, e.g. measuring distances, cleaning, for sonography in medical imaging and in wastewater treatment. In food processing, it is used for the purposes of extraction, cleaning, emulsification and homogenisation. Because US is acoustic energy, ionizing and invasive effects can be excluded from consideration. Moreover, this technology uses a non-polluting form of mechanical energy and is therefore considered an emerging method for food processing which does not interfere with food quality, and which has high consumer acceptance.

Under exposure to US, compression and rarefaction are induced in the molecules of the medium in question. As a consequence of the pressure changes induced by the impingement of high-speed liquid jets and hydrodynamic shear forces, microbubbles are formed in liquid media, which expand and then implode. This phenomenon is called 'acoustic cavitation'. 
Table 3 Overview on inactivation effects of plasma-based technology on different bacteria

\begin{tabular}{|c|c|c|c|c|c|}
\hline Technology & Matrix & Bacterial species & Parameter & Maximum reduction & Reference \\
\hline \multirow[t]{12}{*}{$\begin{array}{l}\text { Dielectric barrier } \\
\quad \text { discharge plasma (DBD) }\end{array}$} & Chicken breast & $\begin{array}{l}\text { Campylobacter jejuni } \\
\text { Salmonella Typhimurium }\end{array}$ & $70 \mathrm{kV}, 300 \mathrm{~s}+5$-day storage & About $1 \log \mathrm{CFU} / \mathrm{ml}$ & {$[69]$} \\
\hline & Chicken breast & Listeria monocytogenes & $2-100 \mathrm{~W}, 15 \mathrm{kHz}, 10 \mathrm{~min}$ & $2.14 \log \mathrm{CFU} / \mathrm{g}$ & {$[54]$} \\
\hline & & Escherichia coli & & $2.73 \log \mathrm{CFU} / \mathrm{g}$ & \\
\hline & & Salmonella Typhimurium & & $2.71 \log \mathrm{CFU} / \mathrm{g}$ & \\
\hline & Beef & Escherichia coli $(n=4)$ & $20 \mathrm{MHz}, 6 \mathrm{kV} .5 \mathrm{~min}$ & $1.82 \log \mathrm{CFU} / \mathrm{cm}^{2}$ & {$[71]$} \\
\hline & Beef loin & Listeria monocytogenes & $\mathrm{N}_{2}$ and $\mathrm{O}_{2}, 2 \mathrm{~W}, 15 \mathrm{kHz}, 10 \mathrm{~min}$ & $1.90 \log \mathrm{CFU} / \mathrm{g}$ & {$[72]$} \\
\hline & & Escherichia coli $\mathrm{O} 157: \mathrm{H} 7$ & & $2.57 \log \mathrm{CFU} / \mathrm{g}$ & \\
\hline & & Salmonella Typhimurium & & $2.58 \log \mathrm{CFU} / \mathrm{g}$ & \\
\hline & Pork butt & Listeria monocytogenes & & $2.04 \log \mathrm{CFU} / \mathrm{g}$ & \\
\hline & & Escherichia coli $\mathrm{O} 157: \mathrm{H} 7$ & & $2.54 \log \mathrm{CFU} / \mathrm{g}$ & \\
\hline & & Salmonella Typhimurium & & $2.68 \log \mathrm{CFU} / \mathrm{g}$ & \\
\hline & Chicken breast & Salmonella & $14.5 \mathrm{~W}, 10 \mathrm{~min}$ & $3.7 \log \mathrm{CFU} / \mathrm{s}$ & {$[68]^{*}$} \\
\hline \multirow{2}{*}{$\begin{array}{l}\text { Corona discharge } \\
\text { plasma jet (CDPJ) }\end{array}$} & Pork & Escherichia coli $\mathrm{O} 157: \mathrm{H} 7$ & $58 \mathrm{MHz}, 20 \mathrm{kV}, 90-120 \mathrm{~s}$ & $1.5 \log \mathrm{CFU} / \mathrm{g}$ & [73] \\
\hline & & Listeria monocytogenes & & $1.0 \log \mathrm{CFU} / \mathrm{g}$ & \\
\hline \multirow{2}{*}{$\begin{array}{l}\text { Atmospheric pressure } \\
\text { plasma jet }\end{array}$} & Chicken skin & Campylobacter jejuni $(n=2)$ & $1 \mathrm{MHz}, 2-3 \mathrm{kV} .180 \mathrm{~s}$ & About $2.5 \log \mathrm{CFU} / \mathrm{cm}^{2}$ & {$[57]$} \\
\hline & Chicken breast & & & About $2.5 \log \mathrm{CFU} / \mathrm{cm}^{2}$ & \\
\hline \multirow{4}{*}{$\begin{array}{l}\text { Plasma-activated water } \\
\text { and ultrasound }\end{array}$} & Chicken skin & Escherichia coli $\mathrm{K} 12$ & $1.5 \mathrm{MHz}, 6.8 \mathrm{kV}, 40 \mathrm{~Hz} .60 \mathrm{~min}, 40^{\circ} \mathrm{C}$ & $1.12 \log \mathrm{CFU} / \mathrm{ml}$ & {$[58]$} \\
\hline & & Staphylococcus aureus & & $0.86 \log \mathrm{CFU} / \mathrm{ml}$ & \\
\hline & Chicken meat & Escherichia coli $\mathrm{K} 12$ & & $1.33 \log \mathrm{CFU} / \mathrm{ml}$ & \\
\hline & & Staphylococcus aureus & & $0.83 \log \mathrm{CFU} / \mathrm{ml}$ & \\
\hline $\begin{array}{l}\text { Atmospheric cold } \\
\text { plasma and peracetic } \\
\text { acid (PAA) }\end{array}$ & Chicken meat & Salmonella Typhimurium & $\begin{array}{l}0 \text { to } 30 \mathrm{kV}, 3.5 \mathrm{kHz}, 4{ }^{\circ} \mathrm{C}, \mathrm{PAA} \\
(100-200 \mathrm{ppm}), 60 \mathrm{~min}, 0 \text { to } 30 \\
\mathrm{kV}, 3.5 \mathrm{kHz}, 4^{\circ} \mathrm{C}, \mathrm{PAA} \\
(100-200 \mathrm{ppm}), 60 \mathrm{~min}\end{array}$ & $5.3 \log \mathrm{CFU} / \mathrm{cm}^{2}$ & {$[74 \bullet]$} \\
\hline $\begin{array}{l}\text { Cold nitrogen plasma } \\
\text { and lemongrass oil }\end{array}$ & Pork loin & Listeria monocytogenes & $\begin{array}{l}500 \mathrm{~W}, 120 \mathrm{~s} \text { and lemongrass oil } \\
5 \mathrm{mg} / \mathrm{mL}, 30 \mathrm{~min}\end{array}$ & $2.8 \log \mathrm{CFU} / \mathrm{g}$ & {$[56]$} \\
\hline $\begin{array}{l}\text { Plasma-activated } \\
\text { lactic acid (PALA) }\end{array}$ & Beef slices & Salmonella Enteritidis & $19.2 \mathrm{kV}, 80 \mathrm{~s}$, PALA $0.2 \%$ & $3.52 \log \mathrm{CFU} / \mathrm{g}$ & {$[55]$} \\
\hline
\end{tabular}

*Two-dimensional array of integrated, coaxial, microhollow, dielectric barrier discharge plasma

CFU: colony-forming units

This mode of action can have various effects on living and nonliving materials. US is thus used in a variety of applications, including the antimicrobial treatment of food. For such purposes, it is assumed that the phenomenon of cavitation leads to the thinning of cell membranes, the generation of heat and the production of free radicals, which itself can damage cell membranes and DNA $[110,111]$. It has been shown that grampositive bacteria are more resistant to US than gram-negative bacteria due to their thicker cell walls $[112,113]$.

Reviews show that the response to US of pathogenic and spoilage microorganisms in meat and meat products depends on many factors, such as acoustic energy and density, temperature and exposure time and product parameters such as $\mathrm{pH}$, water activity, salt content and the presence of antimicrobials [114]. Although the antimicrobial effect of US is known, only a few studies consider it to be an alternative for the decontamination of carcasses and fresh meat surfaces.

Over the past decade, the majority of studies have used poultry meat and skin in order to examine the antimicrobial effect of US. In brief, various treatments were applied to artificially contaminated chicken meat, and showed no reduction, or only a slight reduction, in Campylobacter or Salmonella spp. [46, 103, 104, 115, 116] (Table 4). Similar results were obtained for Salmonella spp. and Staphylococcus aureus following a US bath, even after 50 min of treatment [105].

By contrast, it is evident that the antimicrobial effect of other non-thermal treatments, such as marination, chlorination, treatment with lactic acid, ethanol or with plasmaactivated water is enhanced if combined with US technology [58, 103, 117-119].

Besides its antimicrobial effect, US is known to enhance various mass transfer processes, e.g. during the curing and pickling of meat. Furthermore, the use of US to trigger the tenderisation of meat has also been discussed [114]. All potential applications of US in the meat industry have been summarized in various review articles such as Alarcon-Rojo [120], Misra et al. [114] and Rosario et al. [121].

In conclusion, although data have shown that the treatment of raw meat surfaces using US alone can reduce bacterial load, the achieved reduction rates are low compared to those associated with other physical technologies. However, US can enhance antimicrobial impact in combination with biological or chemical treatments and is therefore a promising tool in terms of a combined hurdle concept for use during meat processing. In this context, future research and development are needed in order to implement the technology at an industrial scale. 
Table 4 Overview on inactivation effects of high hydrostatic pressure and ultrasound on different bacteria

\begin{tabular}{|c|c|c|c|c|c|}
\hline Technology & Matrix & Bacterial species & Parameter & Maximum reduction & Reference \\
\hline \multirow[t]{18}{*}{$\begin{array}{l}\text { High hydrostatic } \\
\text { pressure }\end{array}$} & $\begin{array}{l}\text { Minced chicken and whole } \\
\text { chicken breast }\end{array}$ & Campylobacter jejuni & $100-200 \mathrm{MPa} ; 5 \mathrm{~min} ; 5^{\circ} \mathrm{C}$ & $0.4 \log \mathrm{CFU} / \mathrm{g}$ & {$[88]$} \\
\hline & Turkey ground poultry & $\begin{array}{l}\text { Campylobacter jejuni } \\
\quad(n=6)\end{array}$ & $250 \mathrm{MPa}, 10 \mathrm{~min}, 4^{\circ} \mathrm{C}$ & $1.1 \log \mathrm{CFU} / \mathrm{g}$ & {$[89]$} \\
\hline & Chicken liver & Campylobacter jejuni & 250-350 MPa; 5, $10 \mathrm{~min}$ & $3.4 \log$ CFU/liver & {$[90]$} \\
\hline & Vacuum-packed chicken filet & Salmonella Enteritidis & 400-600 MPa; 10, $20 \mathrm{~min}$ & $6.5 \log \mathrm{CFU} / \mathrm{g}$ & [91] \\
\hline & Frozen chicken breast filet & Salmonella & $100-600 \mathrm{MPa} ; 1-9 \mathrm{~min}$ & $>5 \log \mathrm{CFU} / \mathrm{g}$ & {$[92]$} \\
\hline & Chicken breast filet & Salmonella & $100-300 \mathrm{MPa} ; 5,10 \mathrm{~min} ; 4^{\circ} \mathrm{C}$ & $5.38 \log \mathrm{CFU} / \mathrm{g}$ & [93] \\
\hline & Ground chicken & Salmonella & 250-450 MPa, $10,15 \mathrm{~min}, 4-6^{\circ} \mathrm{C}$ & $5 \log \mathrm{CFU} / \mathrm{g}$ & [94] \\
\hline & $\begin{array}{l}\text { Chicken and mechanically } \\
\text { recovered poultry meat }\end{array}$ & Listeria innocua & $350-500 \mathrm{MPa} ; 5-30 \mathrm{~min} ; 2,10,20^{\circ} \mathrm{C}$ & $7.78 \log \mathrm{CFU} / \mathrm{g}$ & {$[95]$} \\
\hline & Chicken breast filet & Listeria monocytogenes & 100-300 MPa; 5, $10 \mathrm{~min} ; 4^{\circ} \mathrm{C}$ & $3.4 \log \mathrm{CFU} / \mathrm{g}$ & [93] \\
\hline & Ground chicken & E. coli $0157: H 7$ & $300-500 \mathrm{MPa} ; 15 \mathrm{~min} ;<40^{\circ} \mathrm{C}$ & $7.2 \log \mathrm{CFU} / \mathrm{g}$ & [96] \\
\hline & Ground chicken & E. coli & $300-500 \mathrm{MPa} ; 15 \mathrm{~min} ;<40^{\circ} \mathrm{C}$ & $5.23 \log \mathrm{CFU} / \mathrm{g}$ & \\
\hline & Chicken breast filet & E. coli & $100-300 \mathrm{MPa} ; 5,10 \mathrm{~min} ; 4^{\circ} \mathrm{C}$ & $4.06 \log \mathrm{CFU} / \mathrm{g}$ & [93] \\
\hline & Ground chicken & E. coli & $300-500 \mathrm{MPa}, 5-25 \mathrm{~min}$ & $>6 \log \mathrm{CFU} / \mathrm{g}$ & [7] \\
\hline & Ground chicken & E. coli (22 strains) & $400,600 \mathrm{MPa} 1-4 \mathrm{~min}$ & $>6 \log \mathrm{CFU} / \mathrm{g}$ & {$[97]$} \\
\hline & Ground beef & $\begin{array}{l}\text { E. coli non O157 STEC } \\
(n=6) \text { and O157:H7 }\end{array}$ & $250-450 \mathrm{MPa}, 5,15,30 \mathrm{~min}$ & $6.9 \log \mathrm{CFU} / \mathrm{g}$ & [98] \\
\hline & Beef liver & E. coli & 200-500 MPa, $10-30 \mathrm{~min}, 25^{\circ} \mathrm{C}$, & $5 \log \mathrm{CFU} / \mathrm{g}$ & [99] \\
\hline & Ground beef & E. coli O157:H7 $(n=6)$ & $400 \mathrm{MPa}, 25-45^{\circ} \mathrm{C}, 1-5$ cycles & $8 \log \mathrm{CFU} / \mathrm{g}$ & {$[100]$} \\
\hline & $\begin{array}{l}\text { Pork organs (liver, lung, } \\
\text { heart, kidney) }\end{array}$ & Salmonella (4 serovars) & $400-600 \mathrm{MPa}, 4 \mathrm{~min}$ & 4.6/4.4/3.6/4.5 log CFU/ $\mathrm{cm}^{2}$ & [101] \\
\hline \multirow[t]{6}{*}{ Ultrasound } & Chicken skin & Salmonella Typhimurium & $37 \mathrm{kHz}, 380 \mathrm{~W}, 5 \mathrm{~min}$ & No significant reduction & {$[102]$} \\
\hline & Chicken skin & Campylobacter jejuni & $37 \mathrm{kHz}, 380 \mathrm{~W}, 5 \mathrm{~min}$ & No significant reduction & \\
\hline & Chicken skin & Salmonella Typhimurium & $37 \mathrm{kHz}, 380 \mathrm{~W}$ & No significant reduction & {$[103]$} \\
\hline & Chicken skin & Salmonella Typhimurium & $37 \mathrm{kHz}, 380 \mathrm{~W}, 5 \mathrm{~min}$ & No significant reduction & {$[104]$} \\
\hline & Chicken drumsticks & Campylobacter jejuni & $40 \mathrm{kHz}, 20 \mathrm{~W} / \mathrm{l}, 16 \mathrm{~min}$ & No significant reduction & [53] \\
\hline & Chicken breast & $\begin{array}{l}\text { Salmonella } \\
\quad \text { Staphylococcus aureus }\end{array}$ & $40 \mathrm{kHz}, 9.6 \mathrm{~W} / \mathrm{cm}^{2}, 50 \mathrm{~min}$ & No significant reduction & {$[105]$} \\
\hline
\end{tabular}

CFU: colony-forming units

\section{Conclusions}

This review has examined recent research reports which focused on several non-thermal technologies (irradiation, pulsed light, UV-C light, cold plasma, high pressure and ultrasound), for use in reducing the presence of microorganisms on raw meat surfaces whilst minimizing loss of food quality. These treatments are environmentally friendly, free of chemicals and leave no residues, and one procedure alone is usually sufficient to decrease the pathogenic load on meat significantly. The time needed for the successful application of the different techniques varies; in the case of UV-C or pulsed light, the microorganisms on the product surface are reduced within seconds, but a much longer exposure time is required when using ultrasound. However, it has been shown that gramnegative pathogens often react more sensitively than grampositive pathogens and spores. For this reason, some authors suggest a combination of methods to achieve sterility effects, if necessary. However, more data are needed in order to optimize individual and synergistic treatments whilst maintaining the organoleptic properties and quality parameters of meat and meat products.
Additionally, food safety laws vary from country to country, so some technologies may not yet be permitted in some countries. Thus, it is not possible to deduce which method will prove to be the best.

In conclusion, it ought to be emphasized that the application of the decontamination procedures described above should be regarded as a supporting measure for combatting food-relevant infectious agents. Under no circumstances should they replace hygiene measures: good hygiene practice remains a priority.

Funding Open Access funding enabled and organized by Projekt DEAL.

Open Access This article is licensed under a Creative Commons Attribution 4.0 International License, which permits use, sharing, adaptation, distribution and reproduction in any medium or format, as long as you give appropriate credit to the original author(s) and the source, provide a link to the Creative Commons licence, and indicate if changes were made. The images or other third party material in this article are included in the article's Creative Commons licence, unless indicated otherwise in a credit line to the material. If material is not included in the article's Creative Commons licence and your intended use is not permitted by statutory regulation or exceeds the permitted use, you will need to obtain permission directly from the copyright holder. To view a copy of this licence, visit http://creativecommons.org/licenses/by/4.0/. 


\section{References}

Papers of particular interest, published recently, have been highlighted as:

- Of importance

•- Of major importance

1. EFSA. The European Union one health 2018 zoonoses report. EFSA J. 2019;17(12):5926. https://doi.org/10.2903/j.efsa.2019. 5926.

2. EFSA. Scientific Opinion on Campylobacter in broiler meat production: control options and performance objectives and/or targets at different stages of the food chain. EFSA J. 2011;9(4):2105. https://doi.org/10.2903/j.efsa.2011.2105.

3. Maherani B, Hossain F, Criado P, Ben-Fadhel Y, Salmieri S, Lacroix M. World market development and consumer acceptance of irradiation technology. Foods. 2016;79(5). https://doi.org/10. 3390/foods5040079.

4. Jayathilakan K, Sultana K, Pandey MC. Radiation processing: an emerging preservation technique for meat and meat products. Def Life Sci J. 2017;2(2):133-41. https://doi.org/10.14429/dlsj.2. 11368.

5. Miller RB. Electronic irradiation of foods: an introduction to the technology. New York: Springer Science; 2005. p. 295.

6. Kwon JH. Safety and understanding of irradiation food. Seoul:SY Yoo and KW Lee Korea Food Safety Research Institute; 2010.

7. Sommers CH, Scullen OJ, Sheen S. Inactivation of uropathogenic Escherichia coli in ground chick meat using high pressure processing and gamma radiation and in purge and chicken meat surfaces by ultraviolet light. Front Microbiol. 2016;7:413. https://doi. org/10.3389/fmicb.2016.00413.

8. Kundu D, Gill A, Lui C, Goswami N, Holley R. Use of low dose e-beam irradiation to reduce $E$. coli $\mathrm{O} 157: \mathrm{H} 2$, non -O157 (VTEC) E. coli and Salmonella viability on meat surfaces. Meat Sci. 2014;96:413-8. https://doi.org/10.1016/j.meatsci.2013.07.034.

9. Black JL, Jaczynski J. Temperature effect on inactivation kinetics of Escherichia coli $\mathrm{O} 157: \mathrm{H} 7$ by electron beam in ground beef, chicken breast meat, and trout fillets. J Food Sci. 2006;71(6): M221-7. https://doi.org/10.1111/j.1750-3841.2006.00105.x.

10. Cap M, Cingolani C, Lires C, Mozgovoj M, Soteras T, Sucari A, et al. Combination of organic acids and low-dose gamma irradiation as antimicrobial treatment to inactivate Shiga toxin-producing Escherichia coli inoculated in beef trimmings: lack of benefits in relation to single treatments. PLoS One. 2020;15(3):e0230812. https://doi.org/10.1371/journal.pone.0230812.

11. Kawasaki S, Saito M, Mochida M, Noviyanti F, Seito H, Todoriki S. Inactivation of Escherichia coli $\mathrm{O} 157$ and Salmonella Enteritidis in ray beef liver by gamma irradiation. Food Microbiol. 2019;78:110-3. https://doi.org/10.1016/j.fm.2018.10. 011.

12. Raut AD, Shashidhar R, Bandekar JR, Kapadnis BP. Effectiveness of radiation processing in elimination of Campylobacter from poultry meat. Radiat Phys Chem. 2012;81(1):82-5. https://doi.org/10.1016/j.radphyschem.2011. 09.003.

13. Xu A, Scullen OJ, Sheen S, Johnson JR, Sommers CH. Inactivation of extraintestinal pathogenic $E$. coli clinical and food isolates suspended in ground chicken meat by gamma radiation. Food Microbiol. 2019;84:103264. https://doi.org/10.1016/j.fm. 2019.103264.

14. Amiri A, Zandi H, Mozaffari KH. Effect of electron beam irradiation on survival of Escherichia coli O157:H7 and Salmonella enterica serovar Thyphimurium in minced camel meat during refrigerated storage. J Food Qual Hazards Control. 2019;6:1748. https://doi.org/10.18502/jfqhc.6.4.1996.

15. Lewis SJ, Velasquez A, Cuppett SL, McKee SR. Effect of electron beam irradiation on poultry meat safety and quality. Poult Sci. 2002;81:896-903.

16. Islam A. Effect of gamma irradiation on shelf life and quality of indigenous chicken meat. JBAU. 2019;4:560-6.

17. Arshad MS, Kwon HJ, Ahmad RS, Ameer K, Ahmad S, Jo Y. Influence of E-beam irradiation on microbiological and physicochemical properties and fatty acid profile of frozen duck meat. Food Sci Nutr. 2020;8(2):1020-9. https://doi.org/10.1002/fsn3. 1386.

18. Roberts PB. Food irradiation is safe: half a century of studies. Radiat Phys Chem. 2014;105:78-82. https://doi.org/10.1016/j. radphyschem.2014.05.016.

19. Heinrich V, Zunabovic M, Varzakas T, Bergmair J, Kneifel W. Pulsed light treatment of different food types with a special focus on meat: a critical review. Crit Rev Food Sci Nutr. 2016;56(4): 591-613. https://doi.org/10.1080/10408398.2013.826174.

20. Kouchma T. Application of infrared and light-based technologies to meat and meat products. In: Cummins EJ, Lyng JG, editors. Emerging technologies in meat processing: production, processing and technology. Chapter 5 book: John Wiley \& Sons, Ltd.; 2016. https://doi.org/10.1002/9781118350676.

21. Dunn J, Ott T, Clark W. Pulsed-light treatment of food and packaging. Food Technol. 1995;49(9):95-8.

22. Kramer B, Wunderlich J, Muranyi P. Recent findings in pulsed light disinfection. J Appl Microbiol. 2016;122(4):830-56. https:// doi.org/10.1111/jam.13389.

23. Elmnasser N, Guillou S, Leroi F, Orange N, Federighi BA. Pulsed-light systems as a novel food decontamination technology: a review. Can J Microbiol. 2007;53:813-21. https://doi.org/10. 1139/W07-042.

24. Wekhof A, Trompeter FJ, Franken O. Pulsed UV disintegration (PUVD): a new sterilisation mechanism for packaging and broad medical-hospital applications. In: Proceedings of the first international conference on ultraviolet technologies, Washington, DC, USA; 2001. p. 14-6.

25. Takeshita K, Shibato J, Sameshima T, Fukunaga S, Isobe S, Arihara K, et al. Damage of yeasts induced by pulsed light irradiation. Int J Food Microbiol. 2003;85:151-8.

26. Farrell HP, Garvey M, Cormican M, Laffey JG, Rowan NJ. Investigation of critical inter-related factors affecting the efficacy of pulsed light for inactivation clinically relevant bacterial pathogens. J Appl Microbiol. 2010;108:1494-508. https://doi.org/10. 1111/j.1365-2672.2009.04545.x.

27. Esbelin J, Maella S, Ram AFJ, Carlin F. Role of pigmentation in protecting Aspergillus niger conidiospores against pulsed light radiation. Photochem Photobiol. 2013;89(3):758-61. https://doi. org/10.1111/7php.12037.

28. Hierro E, Ganan M, Barroso E, Fernandez M. Pulsed light treatment for the inactivation of selected pathogens and shelf-life extension of beef and tuna carpaccio. Int J Food Microbiol. 2012;158:42-8. https://doi.org/10.1016/j.ijfoodmicro.2012.06. 018.

29. Koch F, Wiacek C, Braun PG. Pulsed light treatment for the reduction of Salmonella Typhimurium and Yersinia enterocolitica on pork skin and pork loin. Int J Food Microbiol. 2019;292:64-71. https://doi.org/10.1016/j.ijfoodmicro.2018.11.014.

30. Cassar JR, Mills EW, Campell JA, Demirci A. Decontamination of chicken thigh meat by pulsed ultraviolet light. Meat Muscle Biol. 2019;3(1):479-87. https://doi.org/10.22175/mmb2019.08. 0033.

31. McLeod A, Hovde Liland K, Haugen JE, Sørheim O, Myhrer KS, Holck A. Chicken fillets subjected to UV-C and pulsed UV light: reduction of pathogenic and spoilage bacteria, and changes in 
sensory quality. J Food Saf. 2018;38:e12421. https://doi.org/10. 1111/jfs.12421.

32. Paskeviciute E, Luksiene Z. High-power pulsed light for decontamination of chicken breast surface. Chem Technol 2009;53(4): $1-6$.

33. Keklik NM, Demirci A, Puri VM. Decontamination of unpacked and vacuum-packaged boneless chicken breast with pulsed ultraviolet light. Poult Sci. 2010;89:570-81. https://doi.org/10.3382/ ps.2008-00476.

34. Paskeviciute E, Buchovec I, Luksiene Z. High-power pulsed light for decontamination of chicken from pathogens - a study on antimicrobial efficiency and organoleptic properties. J Food Saf. 2011;31(1):61-8. https://doi.org/10.1111/j.1745-4565.2010. 00267.x.

35. Correa TQ, Blanco KC, Garcia EB, Perez SML, Chianfrone DJ, Morais VS, et al. Effects of ultraviolet light and curcuminmediated photodynamic inactivation on microbiological food safety: a study in meat and fruit. Photodiagn Photodyn Ther. 2020;30:e 101678.

36. Haughton PN, Lyng JG, Cronin DA, Morgan DJ, Fanning S, Whyte P. Efficacy of UV light treatment for the microbiological decontamination of chicken, associated packaging, and contact surfaces. J Food Prot. 2011;74(4):565-72.

37. Sommers CH, Sites JE, Musgrove MT. Ultraviolet light ( $254 \mathrm{~nm})$ inactivation of pathogens on foods and stainless steel surfaces. J Food Saf. 2010;30(2):470-9.

38. Isohanni PMI, Lyhs U. Use of ultraviolet irradiation to reduce Campylobacter jejuni on broiler meat. Poult Sci. 2009;88(3): 661-8.

39. Sommers $\mathrm{CH}$, Sheen S. Inactivation of avirulent Yersinia pestis on food and food contact surfaces by ultraviolet light and freezing. Food Microbiol. 2015;50:1-4

40. Kalchayanand N, Bosilevac JM, King DA, Wheeler TL. Evaluation of UVC radiation and a UVC-ozone combination as fresh beef interventions against Shiga toxin-producing Escherichia coli, Salmonella, and Listeria monocytogenes and their effects on beef quality. J Food Prot. 2020;83(9):1520-9.

41. Kim HJ, Lee YJ, Eun JB. Changes in the microbiological characteristics of Korean native cattle (Hanwoo) beef exposed to ultraviolet (UV) irradiation prior to refrigeration. Korean J Food Sci Anim Resour. 2014;34(6):815-21.

42. Reichel J, Kehrenberg C, Krischek C. Inactivation of Yersinia enterocolitica and Brochothrix thermosphacta on pork by UV-C irradiation. Meat Sci. 2019;158:1-8.e107909.

43. Lee MH, Choi C. Effect of UV or ethanol treatment on the Arcobacter butzleri contaminated on pork. Korean J Food Sci Anim Resour. 2012;32(2):204-11.

44. Yang S, Sadekuzzaman M, Ha S. Reduction of Listeria monocytogenes on chicken breasts by combined treatment with UV-C light and bacteriophage ListShield. LWT Food Sci Technol. 2017;86:193-200.

45. Oh SR, Kang I, Oh MH, Ha SD. Inhibitory effect of chlorine and ultraviolet radiation on growth of Listeria monocytogenes in chicken breast and development of predictive growth models. Poult Sci. 2014;93(1):200-7.

46. Haughton P, Lyng J, Morgan D, Cronin D, Noci F, Fanning S, et al. An evaluation of the potential of high-intensity ultrasound for improving the microbial safety of poultry. Food Bioprocess Technol. 2012;3(5):992-8.

47. Nicorescu I, Nguyen B, Chevalier S, Orange N. Effects of pulsed light on the organoleptic properties and shelf-life extension of pork and salmon. Food Control. 2014;44:138-45. https://doi.org/10. 1016/j.foodcont.2014.03.052.

48. Tomaševiv I, Rajkovic A. The sensory quality of meat, game, poultry, seafood and meat products as affected by intense light pulses: a systematic review. Procedia Food Sci. 2015;5:285-8. https://doi.org/10.1016/j.profoo.2015.09.081.

49. Gayán E, Serrano MJ, Raso J, Álvarez I, Condón S. Inactivation of Salmonella enterica by UV-C light alone and in combinations with mild temperatures. Appl Environ Microbiol. 2012;78(23): 8353-61.

50. Kim SS, Kim SH, Park SH, Kang DH. Inactivation of Bacillus cereus spores on stainless steel by combined superheated steam and UV-C irradiation treatment. J Food Prot. 2020;83(1):13-6.

51. Kujundzic E, Matalkah F, Howard CJ, Hernandez M, Miller SL. UV air cleaners and upper-room air ultraviolet germicidal irradiation for controlling airborne bacteria and fungal spores. J Occup Environ Hyg. 2006;3(10):536- 46.

52. Rastogi RP, Madamwar D, Incharoensakdi A. Multiple defense systems in cyanobacteria in response to solar UV radiation. In: Davison D, editor. Cyanobacteria, chapter 6. book; 2015. p. 125-58. ISBN: 978-1-61470-925-1. https://doi.org/10.13140/ RG.2.1.3270.0889.

53. Haughton PN, Lyng J, Cronin D, Fanning S, Whyte P. Effect of crust freezing applied alone and in combination with ultraviolet light on the survival of Campylobacter on raw chicken. Food Microbiol. 2012;32(1):147-51.

54. Lee H, Yong HI, Kim HJ, Choe W, Yoo SJ, Jang EJ, et al. Evaluation of the microbiological safety, quality changes, and genotoxicity of chicken breast treated with flexible thin-layer dielectric barrier discharge plasma. Food Sci Biotechnol. 2016;25(4):1189-95.

55. Qian J, Zhuang H, Nasiru MM, Muhammad U, Zhang JH, Yan WJ. Action of plasma-activated lactic acid on the inactivation of inoculated Salmonella Enteritidis and quality of beef. Innovative Food Sci Emerg Technol. 2019;57:e 102196.

56. Cui HY, Wu J, Li CZ, Lin L. Promoting anti-listeria activity of lemongrass oil on pork loin by cold nitrogen plasma assist. J Food Saf. 2017;37:e12316.

57. Rossow M, Ludewig M, Braun PG. Effect of cold atmospheric pressure plasma treatment on inactivation of Campylobacter jejuni on chicken skin and breast fillet. LWT. 2018;91:265-70.

58. Royintarat T, Choi EH, Boonyawan D, Seesuriyachan P, Wattanutchariya W. Chemical-free and synergistic interaction of ultrasound combined with plasma-activated water (PAW) to enhance microbial inactivation in chicken meat and skin. Sci Rep. 2020;10(1):e1559. https://doi.org/10.1038/s41598-020-58199-w.

59. Prasad P, Mehta D, Bonsal V, Sangwan RS. Effect of atmospheric cold plasma (ACP) with its extended storage on the inactivation of Escherichia coli inoculated on tomato. Food Res Int. 2017;102: 402-8.

60. Graves DB. The emerging role of reactive oxygen and nitrogen species in redox biology and some implications for plasma applications to medicine and biology. J Phys D Appl Phys. 2012;45(26):e263001

61. Jablonowski H, Bussiahn R, Hammer MU, Weltmann KD, von Woedtke T, Reuter S. Impact of plasma jet vacuum ultraviolet radiation on reactive oxygen species generation in bio-relevant liquids. Phys Plasmas. 2015;22(12):e122008.

62. Baek KH, Yong HI, Yoo JH, Kim JW, Byeon YS, Lim J, et al. Antimicrobial effects and mechanism of plasma activated fine droplets produced from arc discharge plasma on planktonic Listeria monocytogenes and Escherichia coli O157:H7. J Phys D Appl Phys. 2020;53(12):e 124002.

63. Takamatsu T, Uehara K, Sasaki Y, Hidekazu M, Matsumura Y, Iwasawa $\mathrm{A}$, et al. Microbial inactivation in the liquid phase induced by multigas plasma jet. PLoS One. 2015:10(7): e0132381.

64. López M, Calvo T, Prieto M, Múgica-Vidal R, Muro-Fraguas I, Alba-Elías F, et al. A review on non-thermal atmospheric plasma for food preservation: mode of action, determinants of effectiveness, and applications. Front Microbiol. 2019;10:e622. 
65. Dasan BG, Mutlu M, Boyaci IH. Decontamination of Aspergillus flavus and Aspergillus parasiticus spores on hazelnuts via atmospheric pressure fluidized bed plasma reactor. Int J Food Microbiol. 2016;216:50-9.

66. Lacombe A, Niemira BA, Gurtler JB, Sites J, Boyd G, Kingsley $\mathrm{DH}$, et al. Nonthermal inactivation of norovirus surrogates on blueberries using atmospheric cold plasma. Food Microbiol. 2017;63:1-5.

67. Misra NN, Jo C. Applications of cold plasma technology for microbiological safety in meat industry. Trends Food Sci Technol. 2017;64:74-86.

68. Aboubakr HA, Nisar M, Nayak G, Nagaraja KV, Collins J, Bruggeman PJ, et al. Bactericidal efficacy of a two-dimensional array of integrated, coaxial, microhollow, dielectric barrier discharge plasma against Salmonella enterica serovar Heidelberg. Foodborne Pathog Dis. 2020;17(3):157-65.

69. Zhuang H, Rothrock MJ, Hiett KL, Lawrence KC, Gamble GR, Bowker BC, et al. In-package air cold plasma treatment of chicken breast meat: treatment time effect. J Food Qual. 2019:1837351. https://doi.org/10.1155/2019/1837351.

70. Kogelschatz U, Eliasson B, Egli W. Dielectric-barrier discharges. Principle and applications. J Phys IV France. 1997;7(C4):47-66.

71. Stratakos A, Grant I. Evaluation of the efficacy of multiple physical, biological and natural antimicrobial interventions for control of pathogenic Escherichia coli on beef. Food Microbiol. 2018;76: 209-18.

72. Jayasena DD, Kim HJ, Yong HI, Park S, Kim K, Choe W, et al. Flexible thin-layer dielectric barrier discharge plasma treatment of pork butt and beef loin: effects on pathogen inactivation and meatquality attributes. Food Microbiol. 2015;46:51-7.

73. Choi S, Puligundla P, Mok C. Corona discharge plasma jet for inactivation of Escherichia coli $\mathrm{O} 157: \mathrm{H7}$ and Listeria monocytogenes on inoculated pork and its impact on meat quality attributes. Ann Microbiol. 2016;66:685-94.

74. Chaplot S, Yadav B, Jeon B, Roopesh MS. Atmospheric cold plasma and peracetic acid-based hurdle intervention to reduce Salmonella on raw poultry meat. J Food Prot. 2019;82(5):87888 This study examined many different hurdles and achieved high reduction rates. The use of more than one hurdle could be a future solution to reduce microbial contamination in the food industry.

75. Kronn TG, Lawrence KC, Zhuang H, Hiett KL, Rothrock MJ, Huang YW, et al. Nonthermal plasma system for extending shelf life of raw broiler breast fillets. Trans ASABE. 2015;58(2):493500 .

76. Wang J, Zhuang H, Hinton AJR, Zhang J. Influence of in-package cold plasma treatment on microbiological shelf life and appearance of fresh chicken breast fillets. Food Microbiol. 2016;60:1426.

77. Zhao Y, Chen RC, Tian EQ, Liu DP, Niu JH, Wang WC, et al. Plasma-activated water treatment of fresh beef: bacterial inactivation and effects on quality attributes. IEEE Trans Radiat Plasma Med Sci. 2020;4(1):113-20.

78. FEI. Entwicklung eines Plasma-basierten Verfahrens zur automatischen ,Off-line'-Dekontamination von Slicermessern in der Lebensmittelindustrie. Projektkurzbericht AIF 19256 BR 2020. https://www.fei-bonn.de/gefoerderte-projekte/ projektdatenbank/aif-19256-br.projekt.

79. Gucker S. Plasma discharges in gas bubbles in liquid water: breakdown mechanisms and resultant chemistry. University of Michigan. 2015; Dissertation.

80. Hahn V, Dikyol C, Altrock B, Schmidt M, Wende K, Ercan UK, et al. Plasma-mediated inactivation of $E$ coli: influence of protein on wet surface and in liquid medium. Plasma Process Polym. 2019;16:e1800164
81. Jung S, Lee CW, Lee J, Yong HI, Yum SJ, Jeong HG, et al. Increase in nitrite content and functionality of ethanolic extracts of Perilla frutescens following treatment with atmospheric pressure plasma. Food Chem. 2017;237:191-7.

82. Jablonowski H, von Woedtke T. Research on plasma medicinerelevant plasma-liquid interaction: what happened in the past five years? Clin Plasma Med. 2015;3(2):42-52.

83. Farkas DF, Hoover DG. High pressure processing. J Food Sci. 2000;65:47-64. https://doi.org/10.1111/j.1750-3841.2000. tb00618.x.

84. Balasubramaniam VM, Barbosa-Cánovas GV, Lelieveld HLM. High pressure processing of food. In: High pressure processing of food - principles, technology and application. New York: Springer Science + Business; 2016. p. 758.

85. Martinez-Monteagudo SI, Saldaña MDA. Chemical reactions in food systems at high hydrostatic pressure. Food Eng Rev. 2014;6: 105-27. https://doi.org/10.1007/s12393-014-9087-6.

86. Patterson MF. Microbiology of pressure-treated foods. J Appl Microbiol. 2005;98:1400-9. https://doi.org/10.1111/j.1365-2672. 2005.02564.x.

87.•- Tamber S. Population-wide survey of Salmonella enterica response to high-pressure processing reveals a diversity of responses and tolerance mechanisms. Appl Environ Microbiol. 2018;84. https://doi.org/10.1128/AEM.01673-17 This work is a comprehensive investigation, including 99 diverse Salmonella enterica strains and 24 serovars, about the diverse resistance to high pressure treatment.

88. Bechstein DV, Popp J, Sudhaus-Joern N, Krischek C. Effect of ethyl-lauroyl-arginate hypochloride in combination with high hydrostatic pressure processing on the microbial load and physicochemical characteristics of minced and portioned chicken breast meat. Poult Sci. 2019;98:966-76. https://doi.org/10.3382/ps/ pey427.

89. Gunther NW, Sites J, Sommers C. The effects of high-pressure treatments on Campylobacter jejuni in ground poultry products containing polyphosphate additives. Poult Sci. 2015;94(9):2297302. https://doi.org/10.3382/ps/pev199.

90. Gunther NW, Abdul-Wakeel A, Ramos R, Sheen S. Evaluation of hydrostatic high pressure and cold storage parameters for the reduction of Campylobacter jejuni in chicken livers. J Food Prot. 2019;82(6):1039-44. https://doi.org/10.4315/0362-028X.JFP-18469.

91. Argyri AA, Papadopoulou OS, Nisiotou A, Tassou CC, Chorianopoulos N. Effect of high pressure processing on the survival of Salmonella Enteritidis and shelf-life of chicken fillets. Food Microbiol. 2018;70:55e64. https://doi.org/10.1016/j.fm. 2017.08.019.

92. Cap M, Paredes PF, Fernández D, Mozgovoj M, Vaudagna SR, Rodriguez A. Effect of high hydrostatic pressure on Salmonella spp inactivation and meat- quality of frozen chicken breast. LWT. 2020;118:108873. https://doi.org/10.1016/j.lwt.2019.108873.

93. Radovčić NM, Ježek D, Markov K, Frece J, Ćurić D, Medić H. The effect of high pressure treatment on the quality of chicken breast meat. Croat J Food Technol Biotechnol Nutr. 2019;14: $76-81$.

94. Sheen S, Cassidy J, Scullen B, Uknalis J, Sommers C. Inactivation of Salmonella spp. in ground chicken using high pressure processing. Food Control. 2015;57:41-7. https://doi.org/10.1016/j. foodcont.2015.04.005.

95. Yuste J, Mor-Mur M, Capellas M, Pla R. Listeria innocua and aerobic mesophiles during chill storage of inoculated mechanically recovered poultry meat treated with high hydrostatic pressure. Meat Sci. 1999;53:251-7.

96. Chien SY, Sheen S, Sommers CH, Sheen LY. Modeling the inactivation of intestinal pathogenic Escherichia coli O157:H7 and uropathogenic $E$. coli in ground chicken by high pressure 
processing and thymol. Front Microbiol. 2016;7:920. https://doi. org/10.3389/fmicb.2016.00920.

97. Xu A, Scullen OJ, Sheen S, Liu Y, Johnson JR, Sommers CH. Inactivation of extraintestinal pathogenic $E$. coli suspended in ground chicken meat by high pressure processing and identification of virulence factors which may affect resistance to high pressure. Food Control. 2020;111. https://doi.org/10.1016/j.foodcont. 2019.107070.

98. Hsu HY, Sheen S, Sites J, Cassidy J, Scullen B, Sommers C. Effect of high pressure processing on the survival of Shiga toxin-producing Escherichia coli (Big Six vs. O157:H7) in ground beef. Food Microbiol. 2015;48:1-7. https://doi.org/10.1016/j.fm. 2014.12.002.

99. Ogihara H, Suzuki H, Michishita M, Hatakeyama H, Okada Y. Effects of high hydrostatic pressure processing on the number of bacteria and texture of beef liver. J Food Qual. 2017;7835714. https://doi.org/10.1155/2017/7835714.

100. Zhou Y, Karwe MK, Matthews KR. Differences in inactivation of Escherichia coli $\mathrm{O} 157: \mathrm{H} 7$ strains in ground beef following repeated high pressure processing treatments and cold storage. Food Microbiol. 2016;58:7e122016. https://doi.org/10.1016/j.fm.2016. 02.010 .

101. Niebuhr SE, Larson EM, Dickson JS. The effects of high hydrostatic pressure on the color, texture and microbiology of selected pork organ meats. Adv Food Process Technol. 2020;3(1):125. https://doi.org/10.29011/2639-3387.100125.

102. Hyun-Jung J, Md Furkanur RM, Md Iqbal H, Dong-Un L, Sang DH. Enhanced elimination of Salmonella Typhimurium and Campylobacter jejuni on chicken skin by sequential exposure to ultrasound and peroxyacetic acid. J Food Saf. 2020;40(4). https:// doi.org/10.1111/jfs. 12803 .

103. Seo MK, Jeong HL, Han SH, Kang I, Ha SD. Impact of ethanol and ultrasound treatment on mesophilic aerobic bacteria, coliforms, and Salmonella Typhimurium on chicken skin. Poult Sci. 2019;98(12):6954-63.

104. Lee NY, Park SY, Kang IS, Ha SD. The evaluation of combined chemical and physical treatments on the reduction of resident microorganisms and Salmonella Typhimurium attached to chicken skin. Poult Sci. 2014;1(1):208-15.

105. Pinon MI, Alarcon-Rojo AD, Renteria AL, Carrillo-Lopez LM. Microbiological properties of poultry breast meat treated with high-intensity ultrasound. Ultrasonics. 2020;102:105680. https:// doi.org/10.1016/j.ultras.2018.01.001.

106. Bak KH, Bolumar T, Karlsson AH, Lindahl G, Orlien V. Effect of high pressure treatment on the color of fresh and processed meats: a review. Crit Rev Food Sci Nutr. 2019;2:228-52. https://doi.org/ 10.1080/10408398.2017.1363712.

107. Simonin H, Duranton F, de Lamballerie M. New insights into the high-pressure processing of meat and meat products. Compr Rev Food Sci Food Saf. 2012;12:285-306. https://doi.org/10.1111/j. 1541-4337.2012.00184.

108. Nielsen HB, Sonne AM, Grunert KG, Banati D, Pollák-Tóth A, Lakner Z, et al. Consumer perception of the use of high-pressure processing and pulsed electric field technologies in food production. Appetite. 2009;52(1):115-26. https://doi.org/10.1016/j. appet.2008.09.010.

109. Pottier L, de Lamballiere M, Bekhit A, Yang H, Rosenthal A. Manipulation of meat quality: high pressure treatment. In: Bekhit A, editor. Advances in meat processing technology. Boca Raton: CRC Press; 2017. p. 169-218.

110. Chandrapala J, Oliver C, Kentish S, Ashokkumar M. Ultrasonics in food processing. Ultrason Sonochem. 2012;19:975-83.

111. Sango DM, Abela D, Mcelhatton A, Valdramidis VP. Assisted ultrasound applications for the production of safe foods. J Appl Microbiol. 2014;116:1067-83.

112. Mukhopadhyay S, Ramaswamy R. Application of emerging technologies to control Salmonella in foods: a review. Food Res Int. 2012;45(2):666-77.

113. Luo H, Schmid F, Grbin PR, Jiranek V. Viability of common wine spoilage organisms after exposure to high power ultrasonics. Ultrason Sonochem. 2012;19:415-20.

114. Misra NN, Cullen PJ, Brijesh KT. Ultrasound processing applications in the meat industry. In: Cummins EJ, Lyng JG, editors. Emerging technologies in meat processing: Production, Processing and Technology. John Wiley \& Sons, Ltd; 2017, pp. 149-170.

115. Smith DP. Effect of ultrasonic margination on broiler breast meat quality and Salmonella contamination. Int J Poult Sci. 2011;10(10):757-9.

116. Vetchapitak T, Shinki T, Sasaki S, Taniguchi T, Luangtongkum T, Misawa N. Evaluation of chemical treatment combined with vacuum and ultrasonication with a water resonance system for reducing Campylobacter on naturally contaminated chicken carcasses. Food Control. 2020;112. https://doi.org/10.1016/j.foodcont.2020. 107087.

117. Birk T, Knøchel S. Fate of food-associated bacteria in pork as affected by marinade, temperature, and ultrasound. J Food Prot. 2009;72(3):549-55.

118. Lillard HS. Bactericidal effect of chlorine on attached Salmonellae with and without sonification. J Food Prot. 1993;56(8):716-7.

119. Kordowska-Wiater M, Stasiak D. Effect of ultrasound on survival of gram-negative bacteria on chicken skin surface. Bull Vet Inst Pulawy. 2011;55:207-10.

120. Alarcon-Rojo AD, Carillo-Lopez LM, Reyes-Villagrana R, Huerta-Jiménez MH, Garcia-Galicia IA. Ultrasound and meat quality: a review. Ultrason Sonochem. 2019;55:369-82.

121. Rosario DKA, Rodrigues BL, Bernardes PC, Conte-Junior CA. Principles and applications of non-thermal technologies and alternative chemical compounds in meat and fish. Crit Rev Food Sci Nutr. 2020:1-21. https://doi.org/10.1080/10408398.2020. 1754755.

Publisher's Note Springer Nature remains neutral with regard to jurisdictional claims in published maps and institutional affiliations. 